\title{
Introduction: The Teaching Legacy of Dr. Katie Geneva Cannon
}

\author{
Kwok Pui Lan \\ Associate Editor
}

\begin{abstract}
This Forum publishes five short essays by former students of Dr. Katie Geneva Cannon, reflecting on how their mentor influenced their development as teachers and educators.
\end{abstract}

When Dr. Katie Geneva Cannon died on August 8, 2018, we lost not only a preeminent womanist thinker and ethicist, but also an influential and inspiring theological educator and teacher. She was the Annie Scales Rogers Professor of Christian Social Ethics at Union Presbyterian Seminary in Richmond, Virginia, and before that she taught at Temple University and other schools. As a well-respected and beloved teacher, her pedagogy has touched the lives of many of her students. To honor Dr. Cannon's teaching legacy, this journal invited several of her former students from different racial and ethnic backgrounds - Stacey M. Floyd-Thomas, Karen K. Seat, Miguel A. De La Torre, Angela D. Sims, and Edwin David Aponte - to share their experiences of studying with her. We asked them to reflect on Dr. Cannon's contributions to womanist pedagogy and provide examples of how she modeled this inside and outside of the classroom. We also invited them to comment on the ways Dr. Cannon's womanist pedagogy has affected their development as teachers and educators.

Dr. Cannon was the author or editor of many articles and seven books, including the groundbreaking volume Black Womanist Ethics (1988) and Teaching Preaching: Isaac Rufus Clark and Black Sacred Rhetoric (2002). Throughout her teaching career, she stressed the need to dismantle white supremacy and combat ignorance about the experience and struggles of black women. She pointed to the importance of creating womanist pedagogical styles and urged "African American women [to] design new modes of rigorous inquiry to teaching critical consciousness in our various disciplines" (Cannon 1993, 29). She wrote articles sharing her teaching philosophy, classroom practices, and vision for theological education in the twenty-first century (Cannon 2003, 2011, 2014).

As a transformative teacher devoted to her students, Dr. Cannon received prestigious awards in recognition of her teaching. She received the 2011 Award for Excellence in Teaching given by the American Academy of Religion and the Award for Excellence in Theological Education, the highest award from the Presbyterian Church (U.S.A.) for those who teach, lead, and support theological education, in honor of her outstanding lifetime contribution.

In her teaching statement for the teaching award from the American Academy of Religion, Dr. Cannon wrote, "As a Christian womanist liberation theological ethicist embodied, mediated knowledge is a fundamental component of my pedagogy. I bring my biotext and students bring their existential stories, rooted in remembering, to the common, centering point in each course of study" (2010). Many faculties have looked to Dr. Cannon for insights in developing their teaching strategies. She was very generous with her time in mentoring the next generation. One of her last publications was on womanist mentoring: she discussed the politics of being a black woman in the classroom, the need to challenge racism and androcentric patriarchy, 
and ways to demystify white knowledge production and academic ethos so that African American women could survive and thrive (2018).

\section{CONTRIBUTORS TO THIS FORUM HONORING DR. KATIE GENEVA CANNON}

Aponte, Edwin David. 2020. "Reflections on the Pedagogy of My Professor and Mentor Katie Geneva Cannon." The Wabash Center Journal on Teaching 1(1): 107-110. https://doi.org/10.31046/wabashjournal.v1i1.1589.

De La Torre, Miguel A. 2020. “Personalizing Katie’s Canon.” The Wabash Center Journal on Teaching 1(1): 97-99. https://doi.org/10.31046/wabashjournal.v1i1.1587.

Floyd-Thomas, Stacey M. 2020. "Teaching the Canon and Cannon Formation as Incarnation and Conjure: Dr. Katie Geneva Cannon as Womanist Mentor and Muse.” The Wabash Center Journal on Teaching 1(1): 87-91. https://doi.org/10.31046/ wabashjournal.vii1.1585.

Seat, Karen K. 2020. “Creating Our Better Selves: The Fruits of Katie Cannon's Womanist Pedagogy.” The Wabash Center Journal on Teaching 1(1): 93-95. https://doi.org/10.31046/wabashjournal.v1i1.1586.

Sims, Angela D. 2020. "Deep Breaths and High Impact Aerobics: Reflecting on Teaching Writing in the Key of Katie Geneva Cannon.” The Wabash Center Journal on Teaching 1(1): 101-105. https://doi.org/10.31046/wabashjournal.v1i1.1588.

\section{PUBLICATIONS BY KATIE G. CANNON}

Cannon, Katie G. 1988. Black Womanist Ethics. Atlanta, GA: Scholars Press.

Cannon, Katie G. 1993. "Womanist Perspectival Discourse and Canon Formation.” Journal of Feminist Studies in Religion 9, no. 1-2: 29-37.

Cannon, Katie G. 2002. Teaching Preaching: Isaac Rufus Clark and Black Sacred Rhetoric. New York. NY: Continuum.

Cannon, Katie G. 2003. “Entering Creatively into the Life-transforming 'Way of Wisdom': The Usefulness of the 'Moving Step Exercises." Teaching Theology and Religion 6, no. 4: 211-213.

Cannon, Katie G. 2010. “A Personal Teaching Statement.” American Academy of Religion Website. https://www.aarweb.org/ sites/default/files/pdfs/Programs_Services/Teaching_Awards/2011/Teaching_Statement.pdf.

Cannon, Katie G. 2011. "Intellectual Faith Practitioners: African American Theological Education in the Twenty-first Century." Journal of the Interdenominational Theological Center 37, no. 1-2: 17-24.

Cannon, Katie G. 2014. "Pedagogical Praxis in African American Theology." In The Oxford Handbook of African American Theology, edited by Katie G. Cannon and Anthony Pinn, 319-330. New York, NY: Oxford University Press.

Cannon, Katie G. 2018. “Womanist Mentoring - African American Perspectives.” In Mentoring: Biblical, Theological, and Practical Perspectives, edited by Dean K. Thompson and D. Cameron Murchison, 118-135. Grand Rapids, MI: William B. Eerdmans Publishing. 